\title{
PENGARUH DEBIT PEMAKAIAN GAS ARGON SEBAGAI GAS PELINDUNG TERHADAP POROSITAS DAN KEKERASAN HASIL REMELTING ALUMINIUM BERBASIS LIMBAH ALUMINIUM BEKAS
}

\author{
Dedy Hernady \\ Jurusan Teknik Mesin \\ Sekolah Tinggi Teknologi YBS Internasional Tasikmalaya \\ Email: dedyhernady@hotmail.com \\ Sodiran \\ Jurusan Teknik Mesin \\ Sekolah Tinggi Teknologi YBS Internasional Tasikmalaya \\ Email: sodiran86@yahoo.com
}

\begin{abstract}
ABSTRAK
Gas argon sebagai gas inert banyak digunakan untuk proses degassing treatment pada peleburan aluminium. Fungsinya sebagai gas pelindung untuk meminimalkan porositas yang terjadi ketika aluminium cair menjadi padat. Porositas terjadi karena gelembung udara terjebak dalam aluminium cair sehingga mengakibatkan menurunnya kekuatan aluminium tersebut. Penelitian ini dilaksanakan untuk mengetahui berapa volume gas argon yang digunakan untuk kondisi langsung digunakan saat alumunium dipanaskan atau menunggu beberapa saat setelah aluminium mulai mencair. Karena gas argon harganya mahal maka penggunaan gas argon harus seefesien mungkin untuk menekan biaya produksi dalam proses pengecoran. Metode penelitian yang digunakan pada penelitian ini adalah menguji langsung proses peleburan aluminium tanpa gas pelindung, dan memakai gas pelindung dengan jeda waktu penyemprotan 10 menit, 15 menit dan 20 menit. Proses pengamatan porositas yang terjadi menggunakan uji SEM. Dari hasil penelitian diperoleh hasil untuk meleburkan aluminium dibutuhkan waktu kurang lebih 25 menit dan gas argon bisa digunakan 10 menit setelah aluminium dipanaskan. Penggunaan gas argon harus diatur sedemikian rupa sehingga menutupi permukaan aluminium cair. Debit gas argon yang cukup besar akan mengakibatkan gas argon banyak terbuang. Porositas yang terjadi dengan waktu jeda penggunaan gas argon 10 menit setelah aluminium di panaskan adalah sekitar 12,78\%.
\end{abstract}

Kata kunci: peleburan aluminium, aluminium, degassing, gas argon.

\begin{abstract}
Argon gas as an inert gas is widely used for process degassing treatment at aluminum smelting. Its function as gas shield to minimize the porosity that occurs when liquid aluminum becomes solid. Porosity occurs because the air bubbles are trapped in liquid aluminum resulting in a decrease in the strength of the aluminum. This study was conducted to find out how much the volume of argon gas used for direct conditions is used when aluminum is heated or wait a while after aluminum begins to melt. Because argon gas is expensive, the use of argon gas must be as efficient as possible to reduce the cost of production in the casting process. The research method used in this research is direct test of aluminum smelting process without shield gas, and using protective shield gas with spray time of 10 minutes, 15 minutes and 20 minutes. Porosity observation that occurs using the SEM test. From the results of the research, the results obtained for the melting aluminum takes approximately 25 minutes and argon gas can be used 10 minutes after the aluminum is heated. The use of argon gas should be arranged in such a way that it covers the liquid aluminum surface. A large argon gas discharge will result in much wasted argon gas. The porosity occurring with the time lag of argon gas usage 10 minutes after the aluminum was heated was about $12.78 \%$.
\end{abstract}

Keywords: aluminum smelting, aluminum, degassing, argon gas.

\section{PENDAHULUAN}

Aluminium adalah salah satu material yang paling banyak dan sering ditemukan dalam kehidupan sehari-hari. Dari peralatan rumah tangga maupun peralatan industri. Material ini sangat menarik bagi dunia industri, karena memiliki sifat yang ringan, ketahanan korosi yang tinggi, densitas yang rendah, 
dapat dibentuk dengan baik, serta memiliki daya konduktivitas yang tinggi, baik konduktivitas panas maupun listrik [3][15].

Bauksit adalah salah satu sumber alumunium, dan banyak terdapat di daerah Bintan dan Kalimantan. Bauksit dapat diolah dengan proses bayer untuk mendapatkan alumina yang selanjutnya diolah kembali untuk mendapatkan alumunium. Untuk menghasilkan $500 \mathrm{~kg}$ alumunium diperlukan $550 \mathrm{~kg}$ bauksit, 450 $\mathrm{kg} \mathrm{NaOH}, 31.5$ ton $\mathrm{H}_{2} \mathrm{O}$ dan 7.5 ton uap. Bauksit dapat juga diolah menggunakan proses elektrolisa. Untuk $1 \mathrm{~kg}$ alumunium diperlukan $4 \mathrm{~kg}$ bauksit, $0.6 \mathrm{~kg}$ karbon, dan criolit [14]. Gambar 1 menunjukkan aluminium billets hasil olahan.

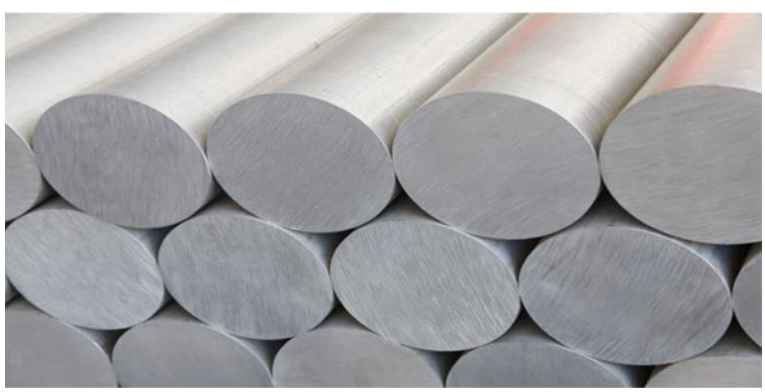

Gambar 1. Aluminium Billets

Aluminium menjadi logam yang luas penggunaannya setelah baja. Material ini merupakan salah satu sumber daya alam yang tidak dapat diperbaharui. Keterbatasan aluminium akhirnya membuat produsen untuk berpikir kreatif dengan cara memanfaatkan limbah hasil pengolahan aluminium, yang disebut remelting. Tujuan dari remelting adalah untuk mengefesiensi bahan yang telah ada, dengan harga yang relatif lebih rendah jika dibandingkan dengan aluminium murni.

Salah satu masalah yang sering timbul dari proses remelting aluminium ini adalah adanya cacat atau porositas pada hasil produknya (Gambar 2). Cacat yang dimaksud berupa cacat porositas gas maupun cacat porositas shrinkage yang umumnya disebabkan oleh pembentukan gas ketika logam cair dituang dan adanya hidrogen yang ikut terlarut. Untuk mengatasi hal tersebut biasanya pada proses peleburan aluminium dilakukan proses degassing.

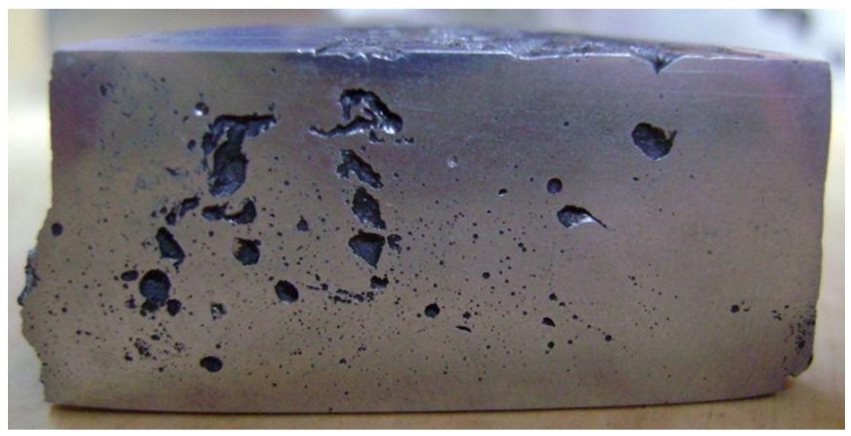

\section{Gambar 2. Cacat Porositas Pada Hasil Pengecoran Aluminium}

Degassing adalah proses pengikatan senyawa hidrogen yang terjadi pada proses peleburan logam aluminium. Hidrogen adalah senyawa terpenting yang mempengaruhi terjadinya cacat porositas pada produk coran. Titik lebur aluminium adalah $660^{\circ} \mathrm{C}$. Bila suhu cairan Al di bawahnya akan terjadi pembekuan yang cepat sehingga hasil coran tidak akan sempurna. Bila suhu cairan logam di atas $660^{\circ} \mathrm{C}$ maka akan terjadi penambahan senyawa hidrogen yang besar. Hasilnya pada produk coran akan terjadi cacat porositas, baik cacat porositas gas maupun cacat porositas shrinkage [7][12]

Proses degassing adalah penambahan unsur-unsur tertentu untuk mengikat hidrogen pada saat proses peleburan. Pada penelitian ini digunakan gas argon sebagai pengikat gas hidrogen yang terjadi pada saat proses peleburan aluminium dan akan diteliti berapa besar debit gas argon yang diperlukan untuk mendapatkan hasil yang terbaik [10]. 


\section{METODOLOGI PENELITIAN}

\subsection{Alat Dan Bahan}

Bahan yang digunakan dalam pengujian ini adalah aluminium. Aluminium yang digunakan pada pengujian ini adalah aluminium komersial yang banyak dijual bebas dan berdasarkan hasil Spektrometri yang dilakukan di laboratorium pengecoran Politeknik Manufaktur Ceper Klaten adalah aluminium seri 6 (ditunjukkan pada Gambar 3) [1][2]. Aluminium mula-mula berbentuk silinder panjang dan untuk lebih memudahkan dan mempersingkat proses peleburan aluminium dipotong-potong dengan ketebalan $2 \mathrm{~cm}$ seperti ditunjukkan pada Gambar 4.a.

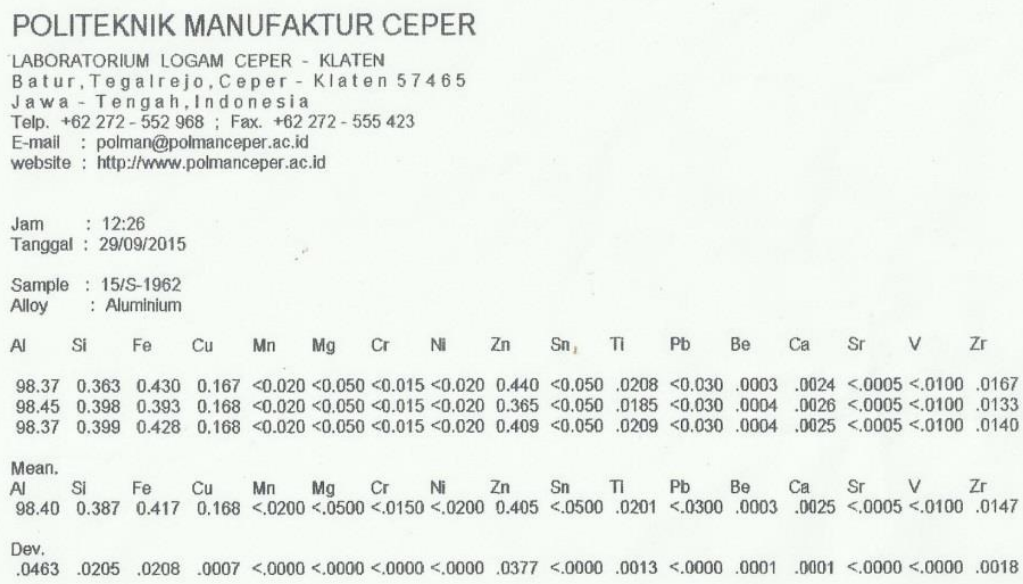

Gambar 3. Hasil Spektrometri Aluminium

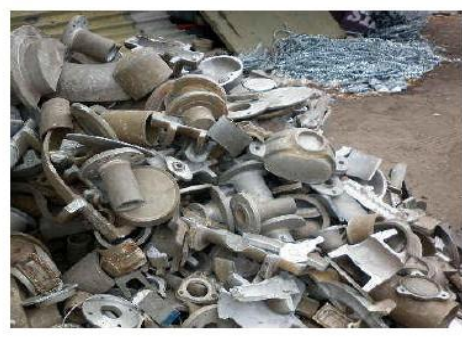

(a)

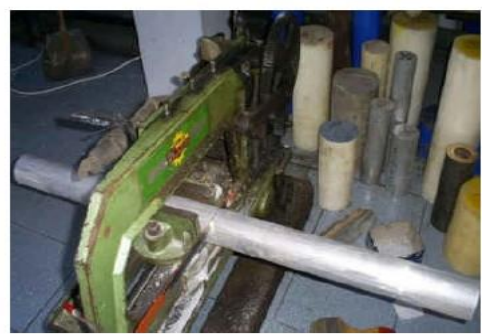

(b)

\section{Gambar 4. (a) Ingot Aluminium Yang Dipakai Pada Penelitian (b) Limbah Aluminium Bekas (Rongsokkan)}

Bahan lain yang digunakan dalam penelitian ini adalah limbah aluminium bekas rongsokkan (ditunjukkan pada Gambar 4.b). Komposisi campuran yang dipakai adalah 70\% ingot aluminium murni dan $30 \%$ limbah aluminium bekas.

\subsection{Proses Peleburan Aluminium}

Peleburan aluminium direncanakan menggunakan bara arang seperti ditunjukkan pada Gambar 5. Proses peleburan yang menggunakan bara arang memerlukan waktu pemanasan awal sekitar 20 menit dan proses peleburan aluminium sampai mencair memerlukan waktu kurang lebih 25 menit. 


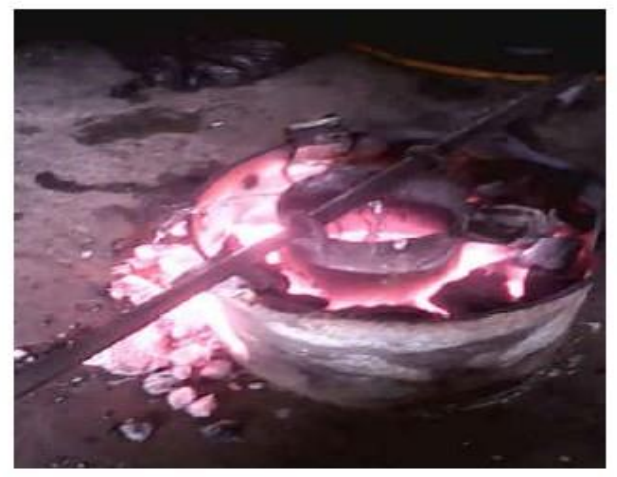

\section{Gambar 5. Proses Peleburan Aluminium Menggunakan Arang Batok}

\subsection{Skema Penelitian}

Dalam penelitian ini peleburan dibagi menjadi 5 kali yaitu :

a. Peleburan pertama tanpa menggunakan gas pelindung, aluminium dilebur selama 25 menit.

b. Peleburan kedua aluminium dilebur selama 25 menit menggunakan gas pelindung argon dari awal sampai selesai.

c. Peleburan ketiga aluminium dilebur selama 25 menit, gas argon digunakan setelah jeda waktu 10 menit dari awal

d. Peleburan ke empat aluminium dilebur selama 25 menit, gas argon digunakan setelah jeda waktu 15 menit dari awal.

e. Peleburan ke lima aluminium dilebur selama 25 menit, gas argon digunakan setelah jeda waktu 20 menit dari awal.

f. Pada saat peleburan aluminium dimasukkan ke dalam tungku setelah tungku mencapai suhu 660 ${ }^{0} \mathrm{C}$ dan di jaga konstan pada saat proses peleburan.

g. Proses peleburan dengan gas pelindung dapat dilihat pada Gambar 6. berikut ini.

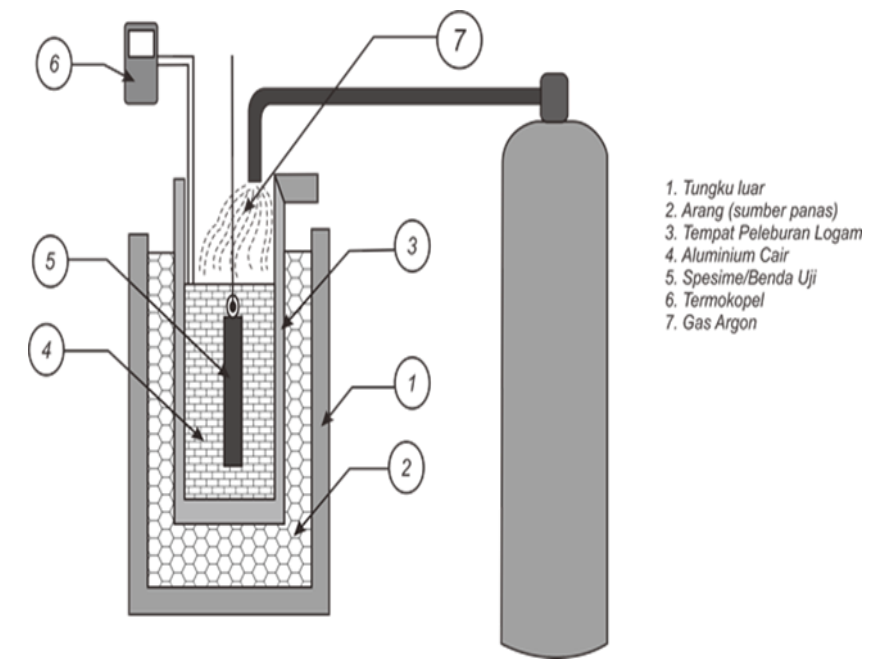

Gambar 6. Proses Peleburan Dengan Degassing Treatment Menggunakan Gas Argon

\subsection{Diagram Alir Penelitian}

Diagram alir pada penelitian ini dapat dituliskan sebagai berikut. 


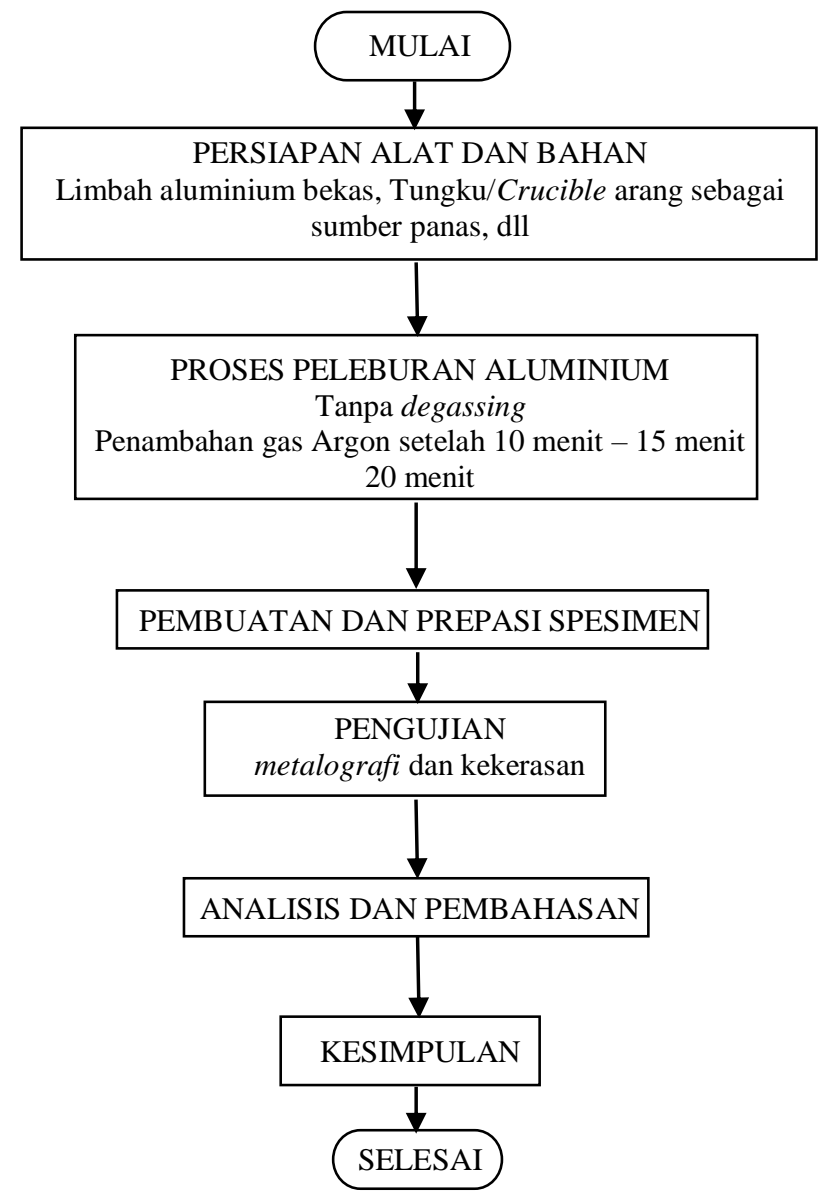

\subsection{Analisis Data}

Untuk pengamatan dan analisis data dilakukan dengan menggunakan pengujian (Scaning Electron Microscope). Pengujian SEM - EDS dilakukan di Politeknik Manufaktur Ceper Klaten yang bekerja sama dengan PT. Multi Teknindo Infotronika Jakarta. Pengujian ini dilakukan terhadap paduan padatan aluminium hasil pengecoran menggunakan mikroskop elektron Phenom Pro X (dapat dilihat pada Gambar 7).

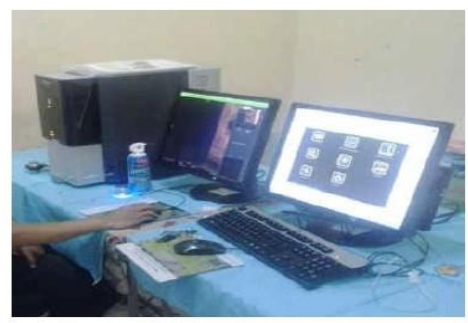

Gambar 7. Mikroskop Elektron Phenom Pro-X

\section{HASIL DAN PEMBAHASAN}

Berdasarkan hasil pengujian SEM didapat hasil sebagai berikut, untuk pengujian peleburan aluminium dengan degassing menggunakan gas argon dimana gas argon disemprotkan pada saat aluminium diberi panas diperlihatkan pada Gambar 8.a. Pengujian peleburan aluminium dengan degassing menggunakan gas argon dimana gas argon disemprotkan setelah 10 menit aluminium dipanaskan diperlihatkan pada Gambar 8.b. Pengujian peleburan aluminium dengan degassing menggunakan gas argon dimana gas argon disemprotkan setelah 15 menit aluminium dipanaskan diperlihatkan pada Gambar 8.c. Pengujian peleburan aluminium dengan degassing menggunakan gas argon dimana gas argon disemprotkan setelah 20 menit aluminium dipanaskan diperlihatkan pada Gambar 8.d. Pengujian peleburan aluminium dengan tanpa degassing diperlihatkan pada Gambar 8.e. 


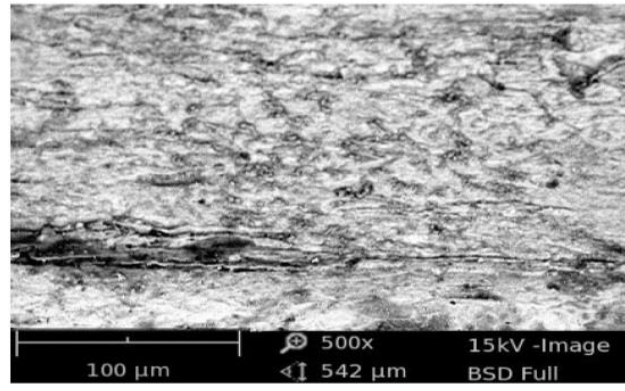

(a)

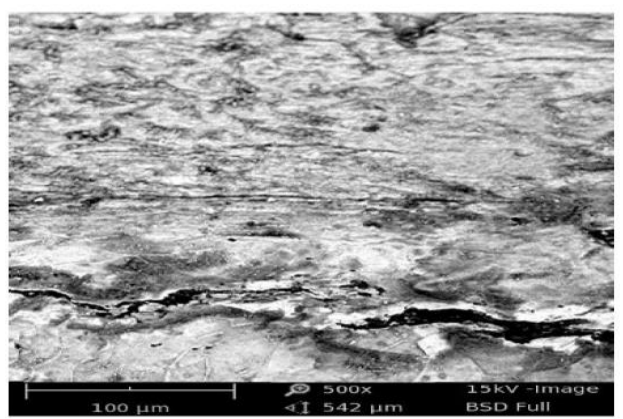

(c)

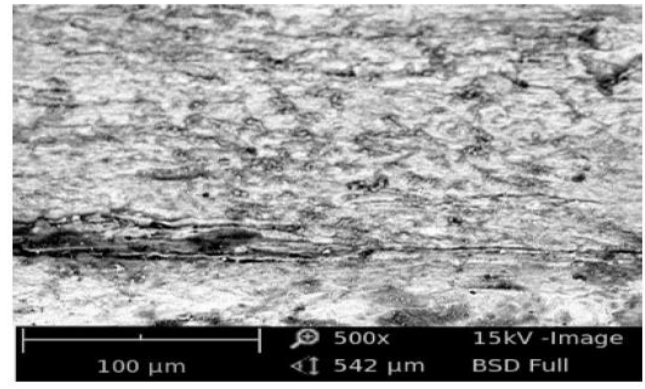

(b)

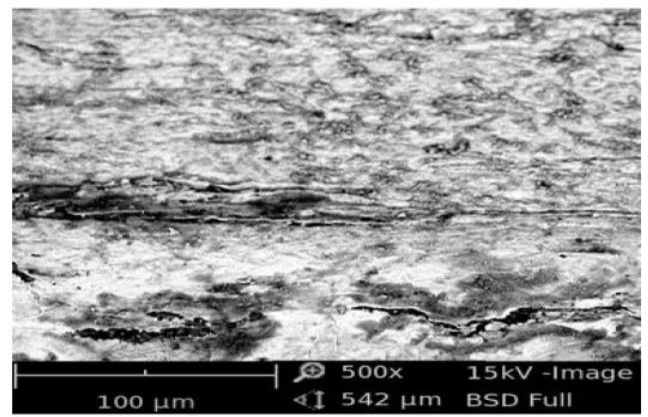

(d)

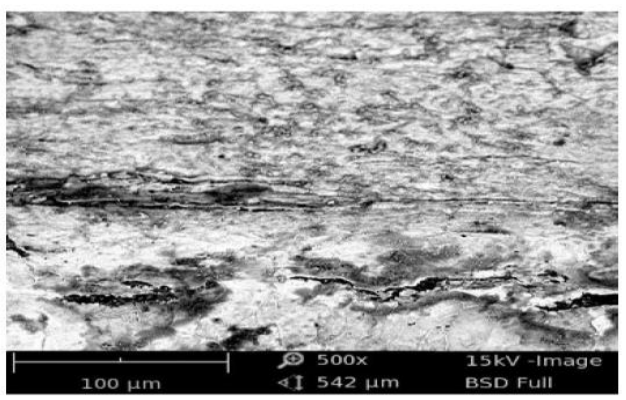

(e)

Gambar 8. Hasil Pengujian Sem (a). Gas Argon Disemprotkan Pada Awal Saat Aluminium Dipanaskan. (b). Gas Argon Disemprotkan 10 Menit Setelah Aluminium Dipanaskan (c). Gas Argon Disemprotkan 15 Menit Setelah Aluminium Dipanaskan. (d). Gas Argon Disemprotkan 20 Menit Setelah Aluminium Dipanaskan. (e). Hasil Peleburan Aluminium Tanpa Degassing

Perhitungan porositas yang terjadi pada hasil peleburan aluminium pada penelitian ini adalah dengan menghitung luas area porositas dibagi dengan luas area yang terbaca. Perhitungan luas porositas menggunakan perangkat lunak AutoCAD 2013 yang memiliki ketelitian sampai $10-6 \mathrm{~mm}$.

Hasil plot gambar hasil uji SEM ke dalam AutoCAD 2013 untuk peleburan aluminium dengan degassing menggunakan gas argon yang disemprotkan bersamaan aluminium dipanaskan diperlihatkan pada gambar 9.a. Untuk peleburan aluminium dengan degassing menggunakan gas argon yang disemprotkan 10 menit setelah aluminium dipanaskan diperlihatkan pada gambar 9.b. Untuk peleburan aluminium dengan degassing menggunakan gas argon yang disemprotkan 15 menit setelah aluminium dipanaskan diperlihatkan pada gambar 9.c. Untuk peleburan aluminium dengan degassing menggunakan gas argon yang disemprotkan 20 menit setelah aluminium dipanaskan diperlihatkan pada gambar 9.d. Untuk peleburan aluminium tanpa degassing diperlihatkan pada gambar 9.e. 


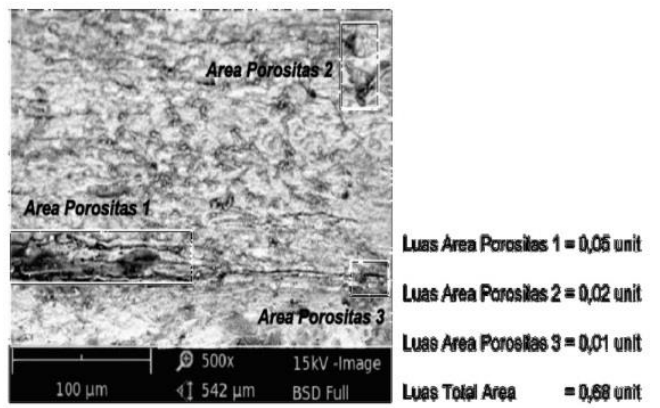

(a)

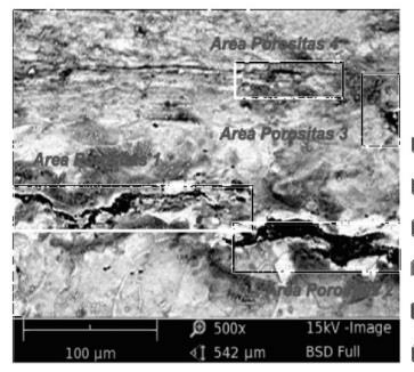

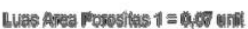

Luss Avea Pososihas g $=0$ a.

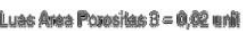

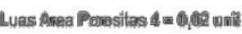
Luas Avo Powosinas 5 = G001 widf Luas Tatal Asea $=1$, 40

(c)

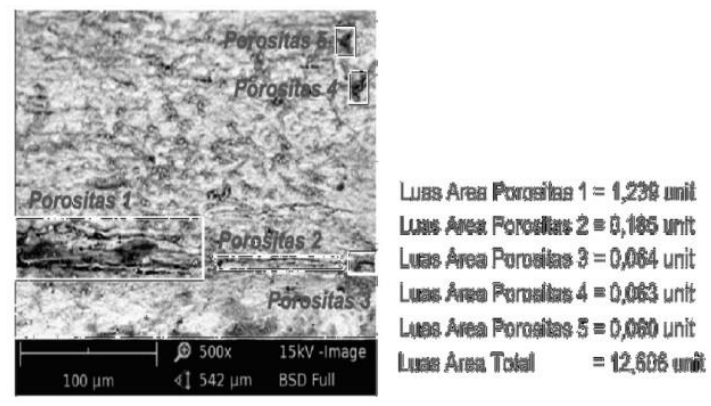

(b)

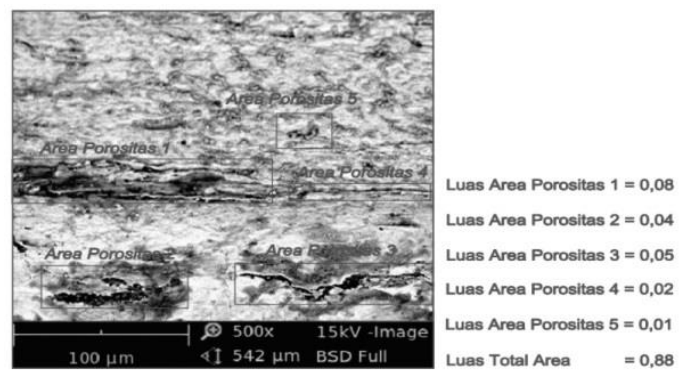

(d)

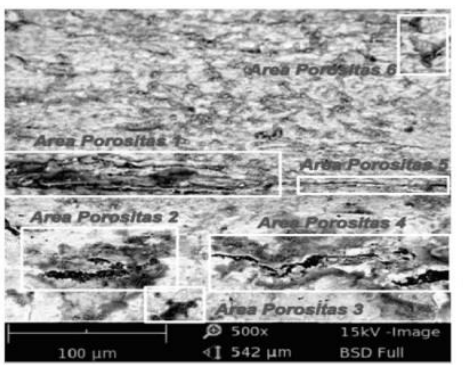

Area Porositas $1=0,08$ un

Luas Area Porositas $2=0,06$ unit

Luas Area Porositas $3=0,01$ unit

Luas Area Porositas $4=0,09$ unit

Luas Area Porositas $5=0,02$ unit

unas Area Porositas $6=0,02$ unit

Luas Total Area $\quad=0,88$ unit

(e)

Gambar 9. (a). Presentase Porositas Untuk Gas Argon Yang Disemprotkan Saat Aluminium Dipanaskan. (b). Presentase Porositas Untuk Gas Argon Yang Disemprotkan 10 Menit Setelah Aluminium Dipanaskan. (c). Presentase Porositas Untuk Gas Argon Yang Disemprotkan 15 Menit Setelah Aluminium Dipanaskan. (d). Presentase Porositas Untuk Gas Argon Yang Disemprotkan 20 Menit Setelah Aluminium Dipanaskan. (e). Presentase Porositas Untuk Peleburan Aluminium Tanpa Degassing

Presentase porositas masing-masing proses telah ditabelkan seperti yang terlihat pada Tabel 1. Grafik presentase porositas yang terjadi akibat waktu jeda penyemprotan gas argon dapat dilihat pada gambar 10.

Tabel 1. Presentase porositas yang terjadi

\begin{tabular}{|c|c|c|c|c|c|c|c|c|c|c|}
\hline \multirow[b]{2}{*}{ No } & \multirow[b]{2}{*}{$\begin{array}{c}\text { Waktu Jeda } \\
\text { Penyemprotan } \\
\text { Gas Argon*) }\end{array}$} & \multicolumn{6}{|c|}{ Luas Area Daerah Porositas } & \multirow{2}{*}{$\begin{array}{c}\text { Total } \\
\text { Luas } \\
\text { Area } \\
\text { Porositas }\end{array}$} & \multirow{2}{*}{$\begin{array}{c}\text { Total } \\
\text { Luas } \\
\text { Area } \\
\text { Terlihat }\end{array}$} & \multirow{2}{*}{$\begin{array}{c}\text { Presentas } \\
e \\
\text { Porositas } \\
\% \\
\end{array}$} \\
\hline & & 1 & 2 & 3 & $\begin{array}{c}4 \\
\text { Satua }\end{array}$ & $\begin{array}{c}5 \\
\text { dalam } ~\end{array}$ & 6 & & & \\
\hline 1 & 0 menit & 0,050 & 0,020 & 0,010 & 0,000 & 0,000 & 0,000 & 0,080 & 0,680 & 11,76 \\
\hline 2 & 10 menit & 1,239 & 0,185 & 0,064 & 0,063 & 0,060 & 0,000 & 1,611 & 12,606 & 12,78 \\
\hline 3 & 15 menit & 0,070 & 0,050 & 0,020 & 0,020 & 0,010 & 0,000 & 0,170 & 1,190 & 14,29 \\
\hline 4 & 20 menit & 0,080 & 0,040 & 0,030 & 0,020 & 0,010 & 0,000 & 0,180 & 0,880 & 20,45 \\
\hline 5 & Tanpa Degasing & 0,080 & 0,060 & 0,010 & 0,090 & 0,020 & 0,020 & 0,280 & 0,880 & 31,82 \\
\hline
\end{tabular}




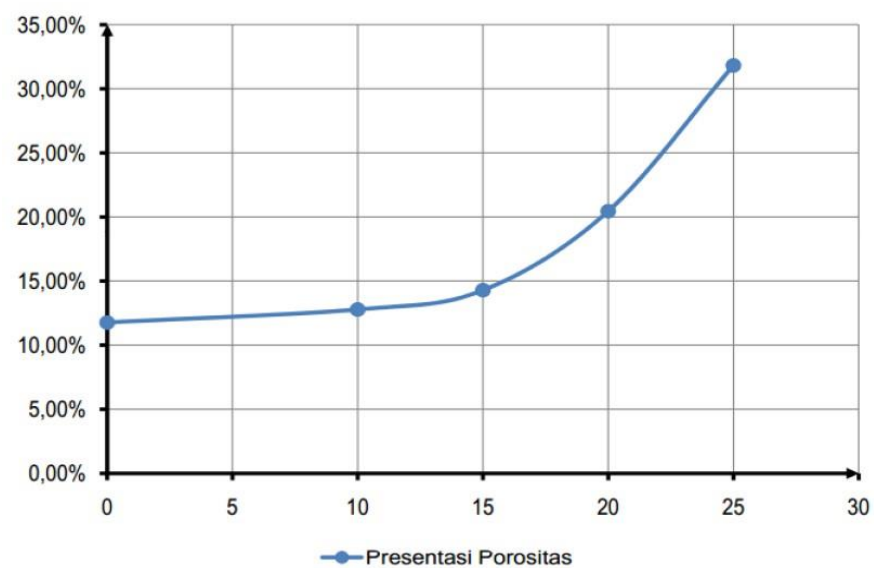

\section{Gambar 10. Grafik Presentase Porositas Yang Terjadi Berdasarkan Waktu Jeda Penyemprotan Gas Argon}

Berdasarkan hasil pengujian diketahui bahwa semakin singkat waktu jeda gas argon disemprotkan porositas yang terjadi semakin kecil. Hasil terbaik diperoleh jika gas argon disemprotkan bersamaan waktunya dengan saat aluminium mulai diberi panas untuk dilebur atau dicairkan. Hal tersebut akan mengakibatkan pemakaian gas argon semakin besar dan hal ini tidak cocok untuk diterapkan pada industri pengecoran logam terutama industri skala kecil karena gas argon mahal harganya.

Dari grafik terlihat bahwa untuk waktu jeda penyemprotan gas argon dari 0 menit sampai 10 menit tidak terjadi kenaikan porositas yang cukup signifikan (dari grafik terlihat garisnya landai). Proses peleburan aluminium rata-rata memakan waktu 25 menit sampai aluminium mencair di luar persiapan dan pemanasan awal. Dalam hal ini untuk menghemat, gas argon bisa disemprotkan minimal 10 menit setelah aluminium diberi panas.

Pemberian gas argon dalam proses peleburan logam aluminium ini adalah salah satu metode degassing untuk mengurangi porositas. Porositas terjadi karena adanya atom hidrogen yang larut dalam aluminium cair. Atom hidrogen yang larut dalam aluminium cair berasal dari disosiasi uap air di permukaan aluminium cair. Atom hidrogen ini akan membentuk gelembung kavitasi kecil karena adanya tekanan. Gelembung kavitasi terjadi karena perubahan tekanan parsial hidrogen pada aluminium cair menjadi lebih kecil daripada tekanan parsial hidrogen di udara luar. Atom hidrogen dalam aluminium cair berdifusi ke gelembung ini dengan mudah dan terus menerus, dan pada saat yang sama berinteraksi satu sama lain dan berubah menjadi molekul hidrogen, yaitu dari $2 \mathrm{H}$ menjadi gas $\mathrm{H}_{2}$. Ketika aluminium cair tersebut membeku gelembung gas $\mathrm{H}_{2}$ ini terjebak dalam paduan aluminium membentuk rongga-rongga yang disebut porositas [6][8].

Konsentrasi maksimum hidrogen yang terlarut pada aluminium paduan sebesar $0,6 \mathrm{ml} \mathrm{H}_{2} / 100 \mathrm{~g}$. Apabila peleburan dilakukan dengan baik kelarutan $\mathrm{H}_{2}$ tersebut dapat dikurangi sehingga menjadi 0,2 $0,3 \mathrm{ml} \mathrm{H}_{2} / 100 \mathrm{~g}$ aluminium. Proses degassing menggunakan gas inert dapat mengurangi tingkat kelarutan hidrogen menjadi sekitar $0,1 \mathrm{ml} \mathrm{H}_{2} / 100 \mathrm{~g}$ aluminium. Kelarutan hidrogen pada paduan cor sekitar $0,12 \mathrm{ml}$ $\mathrm{H}_{2} / 100 \mathrm{~g}$ dan dapat dinyatakan bahwa porositas yang terjadi adalah kecil (Brown, 1999) [5][16].

Menurut Haghayeghi, R (2012) [9], degassing gas argon yang diumpankan ke dalam aluminium cair mempengaruhi gelembung gas tersebut, karena argon tidak dapat larut dalam aluminium cair, maka gas argon bercampur dan menyatu dengan gelembung kavitasi kemudian membawanya ke permukaan sambil mengangkat kotoran yang ada sehingga alumunium cair menjadi bersih dan seragam.

Proses terjadinya porositas dalam peleburan aluminium dipengaruhi juga oleh kecepatan aliran aluminium cair masuk ke dalam cetakan (dies), semakin cepat aluminium cair masuk ke dalam cetakan semakin banyak gelembung gas $\mathrm{H}_{2}$ yang masuk dan terjebak dalam cetakan [4]. Pengaruh lainnya adalah karakteristik bentuk cetakan itu sendiri semakin banyak lekukan maka gelembung gas $\mathrm{H}_{2}$ akan semakin sulit untuk dilepaskan ke udara luar sehingga kemungkinan porositas yang terjadi juga semakin besar [11][13].

Pada proses penelitian ini debit aliran gas argon dialirkan dengan membuka valve pada tabung gas argon. Besaran aliran tidak ditentukan tetapi yang penting gas argon tersebut dapat menutupi permukaan aluminium cair. Semakin singkat waktu jeda gas argon disemprotkan maka semakin besar atau semakin banyak gas argon yang terpakai. Pada pengujian ini dilakukan juga perubahan debit aliran gas argon tetapi tidak berpengaruh malah sebagian besar gas argon banyak yang terbuang. 


\section{KESIMPULAN}

Proses peleburan aluminium dengan degassing menggunakan gas argon dapat mengurangi porositas pada paduan aluminium padat. Pemakaian gas argon untuk mengurangi porositas yang terjadi adalah dengan cara disemprotkan ke dalam aluminium cair. Hasil terbaik untuk penggunaan gas argon untuk metode degassing adalah proses penyemprotannya dilakukan berdasarkan dengan saat aluminium cair dipanaskan di luar persiapan dan pemanasan awal namun hal tersebut akan menyebabkan pemakaian gas argon semakin besar. Hal ini tidak cocok dilakukan dalam proses pengecoran yang dilakukan oleh industri kecil karena gas argon harganya mahal. Debit aliran gas argon tidak terpengaruh terjadinya proses porositas pada paduan aluminium tetapi waktu jeda penyemprotan gas argon yang mempengaruhi terjadinya porositas.

Proses peleburan atau pencairan aluminium sampai mencair memakan waktu kurang lebih 25 menit di luar pemanasan awal dan untuk menghemat pemakaian gas argon, gas argon dapat disemprotkan 10 menit kemudian setelah aluminium padat dipanaskan. Hal ini berdasarkan hasil pengujian bahwa proses penyemprotan dari waktu jeda 0 menit sampai 10 menit tidak terjadi perubahan yang signifikan.

\section{UCAPAN TERIMA KASIH}

Ucapan terima kasih disampaikan kepada Kemristek Dikti yang telah membiayai Penelitian Hibah Penelitian Skema Penelitian Dosen Pemula Tahun 2016, Ketua LPPM dan Seluruh Civitas Akademik Sekolah Tinggi Teknologi YBS Internasional Tasikmalaya, Kepala Laboratorium Pengecoran Logam Politeknik Manufaktur Ceper Klaten beserta staff dan PT. Multi Teknindo Infotronika Jakarta..

\section{DAFTAR PUSTAKA}

[1] -., 1990. Metallography and Microstructures, ASM Handbook, Volume 9, Ohio: ASM International.

[2] -., 1990. Properties and Selection Nonferrous Alloys and Special-Purpose Materials, ASM Handbook Volume 2, Ohio: ASM International.

[3] Amanto, H., Daryanto., 1999. Ilmu Bahan, Bumi Aksara, Jakarta.

[4] Arifin, Bustanul., 1998. Pengecoran Logam Non Ferro, Fakultas Teknik Universitas Indonesia, Jakarta

[5] Brown, John. R., 1999. Foseco Non-Ferrous Foundryman's Handbook, $11^{\text {th }}$ edition, Buttereorth Heinemann, Oxford.

[6] Callister., 2007. Materials Science and Engineering An Introduction, John Wiley \& Sons, Inc, New York.

[7] Dispinar, D.; Akhtar S.; Nordmark, A.; Di Sabatino M.; Arnberg, L, 2010. Degassing, Hydrogen and Porosity Phenomena in A356. Materials Science and Engineering A, (527) page 3719-3725

[8] Glasbrenner, 2000. Scale Structure of Aluminized F82H-mod after HIP Treatment. Elsevier

[9] Haghayeghi., R. Bahai., Kapranos, H., 2012. Effect of ultrasonic argon degassing on dissolved hydrogen in aluminium alloy, Materials Letters 82, hlm. 230-232.

[10] Hidayat, E. 2004. Teknik Peleburan I, Politeknik Manufaktur Ceper, Klaten.

[11] L. Amberg, L. Biickerud, and G. Chai. Solidification Characteristics of Aluminum AIIovs. Vol 3. Dendrite Coherency (American Foundrymen's Society, Inc., 1996), page 115.

[12] Lei Zhao; Ye Pan; Hengcheng Liao; Qigui Wang, 2012. Degassing of Aluminum Alloys During Remelting. Materials Letters (66), page 328-331.

[13] Ren, Y. Wenhui, MA. Kuixian,Wei. Wenzhou,Yu. Kazuki,YD, 2014. Morita Degassing of aluminum alloys via the electromagnetic directional solidification.

[14] Surdia, Tata., Saito, S., 1995. Pengetahuan Bahan Teknik, Pradnya Paramita, Jakarta.

[15] Van Vlack., 2004. Ilmu dan Teknologi Bahan, Erlangga, Jakarta. 
[16] Zhang, Yunhui DU, Shuming XING, Lizhong ZHANG, Daben ZENG, Jianzhong CUI, Limin BA. 2002. Influence of Diffusion Time on Steel-Aluminum Solid do Liquid Bonding Interfacial Structure, J. Mater. Sci. Technol. 18 (05): 468-470 